\title{
The Stateholder Allocation Statement (SAS) AND Decision Making at Private Not-For-Profit Colleges in Western New York
}

\author{
Lawrence R. Hudack
}

Visiting Professor of Accounting

Saint Bonaventure University

School of Business

210B Swan Building

St. Bonaventure, New York 14778

Lhudack@SBU.edu

\begin{abstract}
Two suggestions to improve financial reporting to stakeholders at private not-for-profit colleges are: (1) to use a new financial report format and (2) to adapt a century old financial tool. First, the stakeholder allocation statement (SAS) is introduced to facilitate a better understanding of an institution's financial affairs by key constituents. The SAS reformats the statement of activities away from a bottom line focus to a "fair sharing" emphasis. The revised format helps to promote a collegial process among administrators, faculty, and trustees when making decisions involving the allocation of limited resources. Second, the DuPont financial
\end{abstract}




\section{The BRC Academy Journal of Education Vol. 6, No. 1}

ratio analysis is adapted and applied to not-for-profit institutions. Audited financial data for Saint Bonaventure University, Canisius College, and Niagara University are used to demonstrate these suggestions. Benchmarks are provided to assist in the interpretation of the three colleges' observed allocations and related analyses.

Keywords: not-for-profit, financial reporting, stakeholder allocation statement, DuPont analysis

Data Availability: Data used in this study is available from public sources.

DOI: http://dx.doi.org/10.15239/j.brcacadje.2017.06.01.ja04

\section{INTRODUCTION}

Generally accepted accounting principles (GAAP) that guide not-for-profit financial statements are currently undergoing a thorough review related to numerous proposed changes. The Financial Accounting Standards Board (FASB) has issued an exposure draft: "Not-for-Profit Entities (Topic 958) Presentation of Financial Statements of Not-for-Profit Entities" (April $22,2015)$. Among the areas being examined is the content and format for the statement of activities, as required by the Accounting Standards Codification: ASC 958-225-05. Subsequently, a FASB memorandum (February 10, 2016) states the Board has tentatively decided to improve the presentation of expenses on the required statement of activities. The FASB unanimously voted to enhance disclosures to include reporting expenses by natural classification and to require NFPs to provide enhanced disclosures about the method(s) used to allocate costs among program and support functions. Furthermore, the Board also affirmed the proposal to refine the definition of "management and general activities" and to provide additional implementation guidance to better depict the types of costs that can be allocated among program and/or support functions and those that should not be allocated. While all three of these proposals will enhance the required financial statement for external use, 
the improvements are ignoring critical stakeholders in institutions of higher education. The FASB bias is rooted in its traditional emphasis on providing useful information to investors and creditors, where the NFP trustees and donors replace the investors. This traditional bottom line focus is important to an entity's fiscal sustainability. However, can a university exist without intellectual capital? Why should an integral component of an entity be portrayed as a negative, "necessary evil" via: Revenues - Expenses $=$ Surplus?

The objective of this empirical study is to suggest a new financial report format for internal use to highlight information that enables long-term stakeholders to make rational decisions about the allocation of limited resources. This new format, called a stakeholder allocation statement (SAS), has three primary features:

1. new measures of relevant entity-specific accomplishments, i.e., academic core sum (ACS) and primary operating sum (POS).

2. an effective tool to communicate the allocation of finite resources, and

3. a special emphasis on an entity's financial capital maintenance policy.

Audited financial data from the National Center for Education Statistics (NCES) Integrated Postsecondary Education Data System (IPEDS) is reformatted into a stakeholder allocation statement. In addition, an enhanced DuPont analytical tool is demonstrated to examine the trade-offs with respect to the sharing of resources among a college's stakeholders, its overall financial performance, and ability to borrow funds. The study is based on 48 colleges' financial data for the three most recent years available (2012, $2013 \& 2014)$. The sample selection criteria consisted of colleges classified as private NFP "large masters" schools located in mideastern states. These criteria initially produced 54 schools, but six were removed due to missing data or unusual size which thereby established a sample size of 48. The 48 schools are listed in Appendix A. Three colleges from the Western New York area are highlighted by presenting their SAS 
and DuPont analyses (Saint Bonaventure University, Canisius College, and Niagara University) in order to ensure the paper's relevance at the WNY Business Research Consortium.

\section{WHAT IS A STAKEHOLDER ALLOCATION STATEMENT (SAS)?}

Exhibit 1A illustrates Saint Bonaventure University's stakeholder allocation statement (SAS) for the fiscal years ended 2014, 2013 and 2012. This stakeholder statement is derived from a value-added statement (VAS) format that was recommended in The Corporate Report by the Accounting Standards Steering Committee of the Institute of Chartered Accountants in England and Wales (ICAEW 1975) and the American Accounting Association Committee on Accounting and Auditing Measurement (1991). The ICAEW defines value-added as total revenue (including other income and gains) less conduit costs [i.e., costs incurred by the company in exchange for goods and/or services provided to the company by suppliers]. It is important to note that conduit costs do not include employee-related costs, interest, taxes, depreciation, and amortization expenses. Furthermore, the ICAEW specifies the following five stakeholder allocations to: employees, investors, creditors, government, and the entity itself must be disclosed on the VAS. On a related note, Orsini, Hudack and Zekan (1999) introduced the use of a value-added statement for a private not-for-profit university. Orsini et al. replace investors and government with students, and split the allocation to employees into two groups (faculty and all other employees), in their adaptation of a VAS for a not-for-profit entity.

The stakeholder allocation statement in this study improves the valueadded statement format by fixing three major criticisms. First, the "value added" terminology is eliminated. Value added is misleading when analyzing an institution of higher learning, i.e., many would contend that the value added is the increased knowledge acquired by students. Second, the number of stakeholders is expanded to be consistent with the stakeholder statement's primary purpose, i.e., an inclusive report to 
the providers of both human capital (faculty, administrators, and various support personnel) and financial capital (creditors). Related expenses include direct costs for items such as office supplies, photocopying, conference related costs, etc. for faculty, academic support, student services, and administrators. Auxiliary enterprises frequently refer to direct costs associated with providing room and board services. The physical plant includes direct costs such as maintenance personnel, utilities, property insurance, etc. Finally, the financial assistance to students related to tuition discounts was not used in this study's SAS, due to the lack of an "arm's length" validation; whereas, Orsini et al. did include such an amount in their VAS for a NFP College.

The stakeholder allocation statement is a useful tool to effectively communicate the allocation of finite resources to a not-for-profit entity's stakeholders. This statement forces all stakeholder groups to realize that a trade-off exists. If one group seeks to increase their share, then other group(s) will incur a decrease unless the proverbial pie is made larger, i.e., increase the institution's total revenue and gains. Most importantly, it should be noted that the entity's share for commitments and future operations [resources retained] is to the long-term benefit of the creditors and employees, especially faculty with long-term contracts or tenure. The entity's share is the [A1] surplus / (deficit) plus the [A8] depreciation expense, i.e., a hidden reserve. It is important to note, depreciation is a non-cash flow, accountant created cost allocation that enables the university to retain the necessary resources to refresh / replace fixed assets in order to properly maintain its operations. An equitable goal should be to grow the pie, while maintaining fair shares among the various stakeholders.

The stakeholder allocation statement in Exhibit $1 \mathrm{~A}$ is based on data presented in publicly available information from the university's completed NCES IPEDS survey (available online at www.nces.ed.gov). This informative government survey-based data is derived from the University's audited annual financial statements, with expenses presented 
by functional and natural classifications, rather than by program or activities as prescribed by generally accepted accounting principles (GAAP). It should be noted that the net revenues and gains on the SAS are equal to the GAAP-based amount on the statement of activities. Furthermore, all other aggregate amounts are the same for the GAAP-based financial statements and NCES IPEDS survey. However, the primary difference is the arbitrary cost allocations for depreciation and the physical plant costs to the programs or activities in the GAAP-based statement of activities. In contrast, the prescribed SAS format simply reports these two indirect costs as separate line items.

The SAS introduces two economic measures of entity-specific accomplishments, i.e., academic core sum (ACS) and primary operating sum (POS). The primary operating sum represents distributions of resources to the university's various employees responsible for instruction / research / public service, student advisement, general administration, and the institution itself. The academic core sum places a special emphasis on the allocations to the core employees, who furnish educational and studentfocused academic / advisement support services, in accordance with the University's mission statement. In addition, the bottom section gives special attention to the university's financial capital maintenance policy by the highlighting the relationship between increases to productive (fixed) assets and the depreciation component of resources retained by the entity. An institution must re-invest in its productive (fixed) assets to remain competitive in the future.

The GAAP-based statement of activities for Saint Bonaventure University is presented in Appendix B to compare Exhibit 1A Saint Bonaventure University's stakeholder allocation statement FYE 2014. Key points to note are that both statements have the same amounts for (a) revenues and support/gains equal to $\$ 59,454,802$ (b) total expenses / allocations equal to $\$ 54,013,331$, and (c) surplus equal to $\$ 5,441,471$. (Any minor differences for these three items are due to rounding to the nearest thousand in the SAS.) Meanwhile, the primary difference is how functional expenses are 
reported. The GAAP-based statement uses absorption costing for the report's activities that include arbitrary allocations for both the physical plant and depreciation costs. In contrast, the SAS format is reporting the more relevant direct costs for its reported activities and separate line items for both the physical plant and depreciation costs.

\section{ADAPTING AN ENHANCED DUPONT ANALYSIS OF RETURN ON NET ASSETS}

The stakeholder allocation statement's expanded scope enables a more complete assessment of a university's resources generated with respect to resources retained. Accordingly, the DuPont system of financial analysis is adapted to assess a private NFP college's financial management. The SAS enables the component ratios to be expanded for a more in depth understanding of the factors (allocations of resources to stakeholders) that affect an institution's return on net assets. The expanded version of the DuPont system for a private NFP college is an important process that enables a critical stakeholder group (e.g., faculty) to evaluate its "fair" compensation, while being sensitive to the institution's ability to provide for modern facilities to remain competitive in the future. The latter is particularly important for anyone who desires job security (e.g., tenure) and has many more years until retirement.

Exhibit 2 illustrates the enhanced DuPont analysis, while using data from the private NFP college's stakeholder allocation statements. Eight component ratios for the various stakeholders [A] through [H] are designed to indicate the proportionate sharing of limited resources. A fiscally responsible interpretation of the faculty component [A] should consider the institution's long-term survival in determining an appropriate "fair share" since job security is linked to the university's ability to maintain its competitiveness. For instance, the higher the variable indicates a smaller slice for providers of intellectual capital with respect to a focused proverbial pie. To be more specific, the faculty component represents the sharing of the academic core sum available (after being 
reduced by the compensation and related costs to academic support personnel) between the faculty and the university itself. The supporting calculations for the enhanced analysis that decomposes the university's return on net assets into ten ratio components in accordance with the SAS format are presented in Appendix C.

\section{EMPIRICAL OBSERVATIONS}

Human nature encourages us to ask the question: how will a suggestion for change affect me? Accordingly, three local colleges are highlighted to increase the readers' interest and the study's relevance. The exhibits and figures each have a suffix letter for the following institutions: (A) Saint Bonaventure University, (B) Canisius College, and (C) Niagara University. Exhibit 1 communicates the "big picture" to enable an informed decision when making rather sensitive demands/requests. Can the institution afford to pay the requested salaries and benefits? The current secretive approach by most private institutions often creates a lot of unnecessary bad will and frustration. Figures 1 and 2 are pie charts that attempt to effectively communicate a lot of useful information without a blurryeyed response by the reader. Exhibit 2 depicts specific trade-offs with respect to the sharing of resources among a college's stakeholders, its overall financial performance, and ability to borrow funds.

Saint Bonaventure University's Stakeholder Allocation Statement in Exhibit $1 \mathrm{~A}$ indicates a relatively consistent pattern for allocations to stakeholders over the three-year period. Furthermore, most of these allocation percentages are similar to the three-year averages for the 48 colleges in the study (i.e., three-year norms). The primary differences are for student services and auxiliary operations versus the norms. Furthermore, SBU is using a significant portion of its surplus to replace fixed assets, i.e., over twice the amount of its annual depreciation expense in the fiscal years ended 2014 and 2013 was incurred. Figure 1A presents the SAS allocation percentages in a pie chart to promote a better understanding that the "proverbial pie" has limited resources to share among 
the stakeholders, in accordance with the age-old proverb that a picture is worth a thousand words. Figure $2 \mathrm{~A}$ focuses more specifically on the university's actual resource distributions to stakeholders. These distributions are depicted on a percentage basis of net revenues less the university's share (i.e., the surplus or deficit plus depreciation expense). A focus on actual distributions removes any distortions that may occur during either substandard or exceptional economic years. The FYE 2014 norms $(n=48)$ in Figure 2A are the averages from the 48 colleges for the fiscal year ended 2014 only.

Canisius College's Stakeholder Allocation Statement in Exhibit 1B indicates a relatively consistent pattern for allocations to most stakeholders over the three-year period. However, arguably the two most important stakeholder allocations (retained for future \& faculty) are signs of financial challenges. More specifically the deficit and substandard surplus in 2012 and 2013, respectively, are the problem. Meanwhile, the SAS FYE 2014 appears to be consistent with the three-year norms which is an indication that the financial difficulty has been corrected. Also, Canisuis does make a significant financial commitment to its future in 2013 via an over 4 times its depreciation expense in fixed asset acquisitions. Both Figures 1B and 2B help to communicate Canisius SAS data in a more coherent fashion.

Niagara University's Stakeholder Allocation Statement in Exhibit 1C indicates a relatively consistent pattern for allocations to stakeholders over the two most recent years. Furthermore, most of these allocation percentages are similar to the three-year averages for the 48 colleges in the study (i.e., three-year norms). A noteworthy exception is the significantly higher surplus in the two most recent years. Meanwhile, the FYE 2012 had a substandard surplus which is also reflected in a slightly higher allocation percentage to its faculty. Also, Niagara does make a significant financial commitment to its future in 2013 via an over 4 times its depreciation expense in fixed asset acquisitions. Both Figures $1 \mathrm{C}$ and $2 \mathrm{C}$ help to communicate Niagara's SAS data in a more coherent fashion. 
A general rule of thumb to understand the enhanced DuPont analysis is a higher number is better. With that said, a review of the three colleges reveals the following. First, according to Exhibit 2A SBU's numbers are relatively consistent over the three-year period. The university's return on net assets (RONA), asset turnover, and financial leverage are below the three-year norms. Second, according to Exhibit 2B most of the numbers for Canisius are relatively consistent over the threeyear period. However, significant differences are noted. The college's RONA is significantly below the three-year norms. On a related note, the intellectual capital is well below the norms FYE 2013 and 2012. Also, both the college's asset turnover and financial leverage are below the three-year norms. Third, according to Exhibit 2C Niagara's numbers are relatively consistent over the two most recent years. The university's return on net assets (RONA), asset turnover, and financial leverage are below the three-year norms for FYE 2014 and 2013.

\section{CONCLUDING COMMENTS}

The study's empirically based demonstration is best recapped by the following four noteworthy points: First, "not for profit" does not mean no surplus; the industry's foremost authority, Prager et al. (2010) recommend that private NFP colleges should generate a minimum return of $4 \%$ from its' operating activities. The SAS places a special emphasis on the importance of retaining resources for future operations and commitments. Furthermore, the reporting of "capital additions to depreciation" is critical to understanding the use of surplus for future operations. Second, the absorption costs reported in the functions on the GAAP-based statement of activities are not relevant when making budget decisions related to compensation and direct costs for the entity's stakeholders. Most business entities use the more focused direct costs for internal budget related decisions, while the external audit reports are designed to assist in investment and credit related decisions. Third and most importantly, faculty requests based solely on published average salary and benefits 
paid by other institutions are akin to making decisions in a vacuum. To improve this process, communication of useful financial information to the providers of intellectual capital will facilitate a more harmonious negotiation process. An awareness of the big picture should reduce the likelihood of unreasonable requests and facilitate an acceptance of what the institution can afford to pay its faculty. Transparent reporting of the college's limited financial resources by administrators with faculty should promote a shared responsibility when allocating resources. Fourth, the enhanced DuPont analysis will help the college's Accounting and Finance Faculty to become knowledgeable about their institution's sharing of resources among stakeholders, its overall financial performance, and credit worthiness. They can then take the lead in assisting their colleagues to appreciate a more cosmopolitan and fiscally responsible perspective.

In closing, a private NFP institution's willingness to open its books and share such vital information, without any distortion from arbitrary cost allocations, is a sign of trust and respect for its providers of intellectual capital. While this study does shed some light on these private NFP colleges' financial affairs, it is albeit almost two years behind the presentday scenario. The releasing of relevant financial information in a moretimely fashion, will improve its usefulness for making rational budget related decisions, and promote harmony within the organization.

\section{REFERENCES}

American Accounting Association. American Accounting Association Committee on Accounting and Auditing Measurement, 1989-90 Accounting Horizons (September 1991).

Financial Accounting Standards Board. FASB Exposure Draft: Not-forProfit Entities (Topic 958) Presentation of Financial Statements of Not-for-Profit Entities (April 22, 2015).

Financial Accounting Standards Board. FASB Memorandum Minutes of Not for Profit Financial Statements Board Meeting (February 3, 2016). 
12 The BRC Academy Journal of Education Vol. 6, No. 1

Institute of Chartered Accountants in England and Wales. The Corporate Report (Position Paper) London, England: ICAEW (1975).

KPMG. Issues In-Depth FASB's Proposed Changes to Not-for-Profit Financial Statements. A publication of KPMG's Department of Professional Practice. Contributing authors: Lisa C. Hinkson, Amanda E. Nelson, Maricela Frausto, and Jared S. Silver. Contributing reviewers: David R. Gagnon, National Audit Leader, Higher Education \& Other Not-for-Profits, and Marc B. Scher, National Audit Leader, Healthcare (May 2015).

Meek, G.K. and S.J. Gray. The Value Added Statement: An Innovation for U.S. Companies? Accounting Horizons (June 1988).

Morley, M.F. The Value Added Statement in Britain. The Accounting Review (July 1979).

Orsini, L.O., L.R. Hudack, and D.L. Zekan. Adding Value. Business Officer. Published by the National Association of College and University Business Officers (NACUBO), Washington, D.C. (June1999).

Prager, Sealy \& Co., LLC; KPMG LLP; and Attain LLC. Strategic Financial Analysis for Higher Education: Identifying, Measuring \& Reporting Financial Risks (Seventh Edition). The authors are: Phil Tahey, Consultant, Former Controller of Johns Hopkins University, and Retired Partner of KPMG LLP , Ron Salluzzo, President, State and Local Government and Higher Education, Attain LLC, and Retired Partner of KPMG LLP, Fred Prager, Managing Director and Founding Partner, Prager, Sealy \& Co., LLC, Lou Mezzina, Partner and National Industry Director, Higher Education, KPMG LLP, Chris Cowen, Former Managing Director, Higher Education Practice, Prager, Sealy \& Co., LLC (2010).

\section{Citation Information}

Hudack, Lawrence R. "The Stateholder Allocation Statement (SAS) and Decision Making at Private Not-For-Profit Colleges in Western New York." The BRC Academy fournal of Education 6, no. 1 (2017): 1-13. http:// dx.doi.org/10.15239/j.brcacadje.2017.06.01.ja04 


\section{WeB APPE NDIX}

A web appendix for this paper is available at:

http://dx.doi.org/10.15239/j.brcacadje.2017.06.01.wa04 
